\title{
Chefs meet scientists: GASTRO-SCIENCE-CHEF 2018
}

\author{
Mouritsen, Ole G.; Sørensen, Pia M.; Flore, Roberto
}

Published in:

International Journal of Gastronomy and Food Science

Link to article, DOI:

10.1016/j.ijgfs.2019.100162

Publication date:

2019

Document Version

Peer reviewed version

Link back to DTU Orbit

Citation (APA):

Mouritsen, O. G., Sørensen, P. M., \& Flore, R. (2019). Chefs meet scientists: GASTRO-SCIENCE-CHEF 2018.

International Journal of Gastronomy and Food Science, 17, [100162]. https://doi.org/10.1016/j.ijgfs.2019.100162

\section{General rights}

Copyright and moral rights for the publications made accessible in the public portal are retained by the authors and/or other copyright owners and it is a condition of accessing publications that users recognise and abide by the legal requirements associated with these rights.

- Users may download and print one copy of any publication from the public portal for the purpose of private study or research.

- You may not further distribute the material or use it for any profit-making activity or commercial gain

- You may freely distribute the URL identifying the publication in the public portal

If you believe that this document breaches copyright please contact us providing details, and we will remove access to the work immediately and investigate your claim. 


\section{Accepted Manuscript}

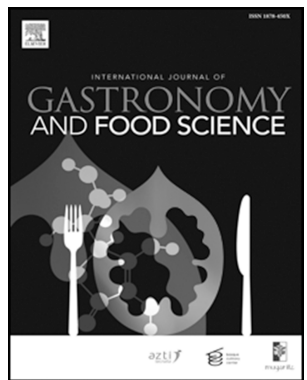

Chefs meet scientists: GASTRO-SCIENCE-CHEF 2018

Ole G. Mouritsen, Pia M. Sörensen, Roberto Flore

PII:

S1878-450X(19)30065-4

DOI:

https://doi.org/10.1016/j.ijgfs.2019.100162

Article Number: 100162

Reference: IJGFS 100162

To appear in: International Journal of Gastronomy and Food Science

Please cite this article as: Mouritsen, O.G., Sörensen, P.M., Flore, R., Chefs meet scientists: GASTROSCIENCE-CHEF 2018, International Journal of Gastronomy and Food Science, https://doi.org/10.1016/ j.ijgfs.2019.100162.

This is a PDF file of an unedited manuscript that has been accepted for publication. As a service to our customers we are providing this early version of the manuscript. The manuscript will undergo copyediting, typesetting, and review of the resulting proof before it is published in its final form. Please note that during the production process errors may be discovered which could affect the content, and all legal disclaimers that apply to the journal pertain. 
Editorial submitted to the special issue

Chefs meet scientists: Gastro-Science-Chef-2018

Int. J. Gast. Food. Sci. (2018)

\section{Editorial}

\section{Chefs meet scientists: GASTRO-SCIENCE-CHEF 2018}

Ole G. Mouritsen

Department of Food Science, Design and Consumer Behavior, University of Copenhagen, 26 Rolighedsvej, DK-1958 Frederiksberg C, Denmark

Pia M. Sörensen

John A. Paulson School of Engineering and Applied Sciences, Harvard University, 29 Oxford Street, Cambridge, MA 02138, USA

Roberto Flore

Office for Innovation and Sector Services, Technical University of Denmark, Diplomvej, Building 373A DTU Skylab, DK-2800 Kgs. Lyngby, Denmark

The last couple of decades have witnessed an increasing interaction between chefs and scientists, fueling new trends in both cooking and in the sciences. In June 2018 an international, two-day topical symposium organized in Copenhagen brought together chefs, scientists, communicators, students, and gastronomical entrepreneurs to discuss in an informal and creative atmosphere matters of mutual interest with the aim of further cross-fertilization and developing new ideas for future and collaborative work. A particular emphasis was on communication and public outreach. The symposium also included workshops with gastronomic and gastrophysical demonstrations and experimentation.

A survey showed that the about 100 participants came both from gastronomy and science, with $35 \%$ self-identifying as scientists or science researchers, $8 \%$ as chefs, and $5 \%$ as both (Fig. 1). Among the participants where also educators (16\%), students (12\%), communicators/journalists (12\%), and gastronomical entrepreneurs or persons from gastronomical businesses (7\%). Survey responders were allowed to choose more than one identity and this is reflected in the survey results.

The goal of the symposium was to bring together professionals from two very different fields - science and gastronomy - as well as those working at the intersection of both. In doing so we hoped to spark new ideas for teaching and research. Moreover, we hoped that the symposium might also inspire novel collaborations in the field, a field which by its very definition relies on cross-talk between disciplines. 
The degree to which we achieved these goals is not straightforward to quantify, but in order to get a sense we summarized our goals in short statements. Attendees were then asked to rate the degree to which they agreed with the statements in a survey. The survey was made available during the first day, but attendees were encouraged not to complete it until the end of the last day.

The majority of respondents either "strongly agreed" or "agreed" with most of the statements (Fig. 2). A large majority, 86\%, agreed or strongly agreed that they had "interacted with professionals in a different field" from their own. In addition, most respondents agreed or strongly agreed that they had met people or attended sessions that "influenced their thinking" (87\%) or "helped them develop ideas for their future work" (79\%). Similarly, many respondents stated having met people they would either stay in touch with $(70 \%)$, or may collaborate with $(68 \%)$, in the future. A remarkable $86 \%$ of respondents stated that they had gained an appreciation for how food and taste can enhance public understanding of science.

We were curious which ideas from the symposium stood out to participants as being especially important. To get a sense, we asked survey responders to list the three most important ideas that they had either developed themselves during the symposium, or heard about from others.

Sometimes survey questions like these highlight that a small number of ideas have resonated with many people, with these ideas being repeated over and over in their answers. That was not the case here. Instead, the three most important ideas reported by survey takers varied widely, only rarely being repeated by a small number of respondents. Perhaps this is to be expected since professionals of diverse backgrounds are likely to differ in their opinion of what they find "important". The answers ranged from topics like "squid" and "jelly-fish" to "holistic cuisine" and "arts and aesthetics in meals" - all having appeared in presentations. Other important ideas were the "role of the chef", "how science and cooking can thrive together", as well as various comments on how food/cooking can be used as teaching tools.

When coaxed for specifics in how they might implement what they learned at the symposium in their work, about a fifth of respondents commented that they would use it in their teaching, with another fifth stating they would use it in their research. About a third reported some aspect of collaborations, such as "explore new collaborations, deepen or refresh existing ones" or "initiating collaborations and writing common grant applications". Many also seemed intrigued by the interdisciplinary aspects raised in the symposium, stating things like being "encouraged" in "approaching people from different disciplines" for "multidisciplinary collaborations". A small number said that it was too early to say how they might implement what they learned at the symposium, reflecting what seemed to be a common notion that collaborations often are not immediate, but may develop over time. 
The present special issue of International Journal of Gastronomy and Food Science contains a collection of sixteen papers under the heading Chefs meet scientists: GASTROSCIENCE-CHEF 2018, which were submitted subsequent to the symposium, mostly from attending speakers. The collection of papers mirrors some of the wide-ranging contents of the symposium, including both original research papers, reviews, short communications, and opinion papers.

The sixteen papers cover diverse topics like soft-matter physics and gastronomy of jelly fish (Thorborg and Vilgis, 2018); the gastrophysics of squid (Faxholm et al., 2018); science education and public understanding of science (Sörensen and Mouritsen, 2018), culinary practioners' views of interaction between gastronomy and research (Fooladi et al., 2018); dining experiences at the inter-section of cooking, research, and communication (Lloréns, 2018); terminological conundrums related to science and gastronomy (Hedegaard, 2018); phycogastronomy (Mouritsen et al., 2018); taste learning in children (Olsen, 2018); teaching science to chefs (Christensen and Edwards-Stuart, 2018); the role of the chef in the 21th century (McBride and Flore, 2018); the holistic cuisine (Brønnum and Munk, 2018); gastronomic research in tempeto (Guixer, 2018); and frames for collaboration between chefs and scientists (Frøst, 2018).

References (to be reformatted and completed when all papers are accepted and paginated)

Mie Thorborg \& Thomas Vilgis: Soft matter physics meet the culinary arts: from polymers to jellyfish

Peter Lionet Faxholm, Charlotte Vinther Schmidt, Louise Beck Brønnum, Yi-Ting Sun, Mathias Porsmose Clausen, Roberto Flore, Karsten Olsen \& Ole G. Mouritsen: Squids of the North: gastronomy and gastrophysics of Danish squid

Pia M. Sörensen and Ole G. Mouritsen: Science education and public understanding of science via food, cooking and flavour

Erik C. Fooladi, Anu Hopia, Dani Lasa \& Juan Carlos Arboleya: Chefs and researchers a survey of culinary practitioners' views of interaction between gastronomy and research

José Lucas Pérez Lloréns: Cooking-research-communication (CRC): the ideal trident to enjoy the dining experience

Liselotte Hedegaard: Gastronomy and Science: Terminological Conundrums

Ole G. Mouritsen, Prannie Rhatigan \& José Lucas Pérez Lloréns: World cuisine of seaweeds: science meets gastronomy

Annemarie Olsen: Taste learning in children - Reflections on current practice 
Morten Christensen \& Rachel Edwards-Stuart: Teaching Science to Chefs: the benefits, challenges and opportunities

Anne McBride \& Roberto Flore: The new role of the chef in the $21^{\text {st }}$ century

Louise Beck Brønnum \& Rasmus Munk: Holistic cuisine - a focus beyond the plate

Bernat Guixer: Tempeto and its derivatives - a case example of gastronomic research based on fermentation.

Michael Bom Frøst: How to create a frame for collaboration between chefs and scientists - business as unusual at Nordic Food Lab 